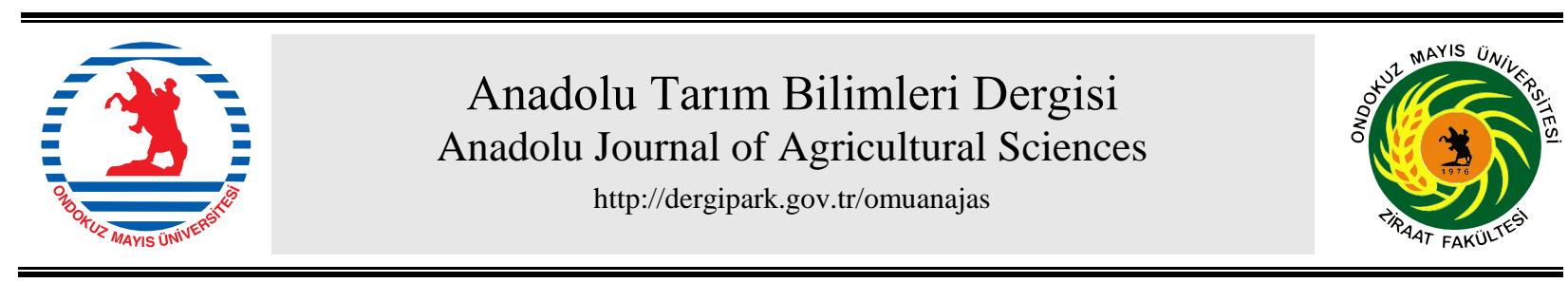

\title{
Bazı arpa (Hordeum vulgare L.) çeşitlerinin in vitro gaz üretimi, organik madde sindirilebilirliği, besin maddeleri içerikleri ve enerji değerlerinin karşılaştırılması
}

\author{
Habip Muruz ${ }^{\mathrm{a},}$, Cansu Çelik ${ }^{\mathrm{b}}$ \\ ${ }^{a}$ Ondokuz Mayls Üniversitesi, Veteriner Fakültesi, Hayvan Besleme ve Beslenme Hastallklarl Anabilim Dalı, Samsun, Türkiye \\ ${ }^{b}$ Ondokuz Mayls Üniversitesi, Sağllk Bilimleri Enstitüsü, Hayvan Besleme ve Beslenme Hastalıklarl Anabilim Dall, Samsun, Türkiye
}

*Sorumlu yazar/corresponding author:habip.muruz@omu.edu.tr

Geliş/Received 12/01/2020 Kabul/Accepted 04/02/2020

ÖZET

Bu çalışma, Türkiye'de yetiştirilen 5 arpa (Hordeum vulgare L.) çeşidinin (Karatay-94, Beyşehir, Ayranc1, Kral-97 ve Larende) kimyasal kompozisyonu, in vitro gaz üretimi (GÜ), organik madde sindirilebilirliği (OMS), metabolik enerji $(\mathrm{ME})$ ve net enerji laktasyon $\left(\mathrm{NE}_{\mathrm{L}}\right)$ düzeylerini belirlemek amacıyla yapılmıştır. Arpa çeşitlerinin nişasta, ham protein (HP), asit (ADF) ve nötr çözeltide (NDF) çözünmeyen lif içerikleri sırasıyla \%50.37-53.17, \%9.72-11.83, \%5.38-8.52, \%19.86-23.37 ve \%1.232.95 arasında olduğu belirlenmiştir. Gaz üretimi, metabolize edilebilir enerji (ME) ve net enerji laktasyon $\left(\mathrm{NE}_{\mathrm{L}}\right)$ ve organik made sindirimine (OMS) ait değerler de sirasıyla 42.23-46.51 mL $200 \mathrm{mg}^{-1}$ kuru madde (KM), 7.74-8.44 ve 4.56-5.0697 $\mathrm{MJ} \mathrm{kg}^{-1} \mathrm{KM}$ ve \%51.79-56.14 arasında değişmiştir. Araştırma sonucunda Larende, Beyşehir, Karatay-97 ve Ayrancı çeşidinin HP içeriği hariç, ADF, NDF ve asit çözeltide çözünmeyen lignin (ADL) içerikleri Kral-97 çeşidine göre daha düşük $(\mathrm{P}<0.001)$ bulunmuştur. Çeşitler arasında nişasta, $\mathrm{GÜ}$ ve $\mathrm{NE}_{\mathrm{L}}$ değerleri benzer bulunurken $\mathrm{OMS}$ ve ME düzeyi Larende çeşidinde Kral-97'den daha yüksek saptanmıştır $(\mathrm{P}<0.05)$. Bu sonuçlar, incelenen arpa çeşitlerinin geviş getiren hayvanların beslenmesinde başarılı bir şekilde kullanılabileceğini göstermiştir.

Comparison of in vitro gas production, organic matter digestibility, metabolizable energy and nutrient contents of the some barley varieties

\footnotetext{
ABSTRACT

This experiment was compare to determine the nutrient contents, gas production (GP), organic matter digestibility (OMD), metabolizable energy (ME) and net energy lactation $\left(\mathrm{NE}_{\mathrm{L}}\right)$ levels of 5 barley (Hordeum vulgare L.) varieties (Karatay-94, Beyşehir, Ayranc1, Kral-97 ve Larende) grown in Turkey. The crude protein content (CP) of barley varieties ranged from 9.72 to $11.83 \%$; neutral detergent fiber (NDF) from 19.86 to $23.37 \%$; acid detergent fiber (ADF) from 5.38 to $8.52 \%$ and acid detergent lignin (ADL) from 1.23 to $2.95 \%$. Total gas production ranged from 42.23 to $46.51 \mathrm{~mL} 200 \mathrm{mg}^{-1} \mathrm{DM}, \mathrm{ME}$ from 7.74 to $8.44 \mathrm{MJ} \mathrm{kg}^{-1} \mathrm{DM}, \mathrm{NE}_{\mathrm{L}}$ from 4.56 to 5.06 , OMD from 51.79 to $56.14 \%$. As a result of this research it has been determined that ADF, NDF and ADL contents of Larende, Beyşehir, Karatay-97 and Ayranc1 were significantly lower than those of Kral-97 $(\mathrm{P}<0.001)$, except for CP; starch, GP and $\mathrm{NE}_{\mathrm{L}}$ were similar among barley varieties. However, OMD and $\mathrm{ME}$ of Larende were significantly higher $(\mathrm{P}<0.05)$ than those of Kral-97. These results showed that the studied barley varieties can be used successfully in the feeding of ruminant animals.
}

Anahtar Sözcükler:

Arpa çeşidi Enerji değeri In vitro gaz üretim Kimyasal kompozisyon Sindirilebilirlik Yem değeri

Keywords: Barley variety Chemical composition Digestibility Energy value Feed value In vitro gas production

(C) OMU ANAJAS 2020 


\section{Giriş}

Arpa (Hordeum vulgare), Türkiye de dahil, tüm dünyada üretim miktarı ve yetiştirme alanı bakımından en önemli tahıllardan birisidir (Kizilgeci ve ark., 2018). Arpa, malt endüstrisinde ve çiftlik hayvanlarının beslenmesinde kullanılmaktadır (Kizilgeci ve ark., 2019; TUIK, 2018). Yem hammaddesi olarak kullanılan arpanın besin maddeleri ve enerji içeriği, dolayısıyla yem değeri, genetik ve çevresel koşullardan dolayı büyük farklılıklar göstermektedir (Reynolds ve ark., 1992; Sanford ve ark., 2003). Nitekim, Reynolds ve ark. (1992) 1600 arpa çeşidinin nişasta ve asit çözeltide çözünmeyen lif (ADF) içeriklerin ve ruminal yıkılabilirliklerinin (18 saat inkubasyon) sirasıly $\% 40.0$ - \%67, içeriği $\% 4.6$ - 18.2 ve $\% 17.5$ - \%72.9 arasında olduğunu bildirmiștir. Farklı arpa genotipleri nötr çözeltide çözünmeyen lif (NDF) içeriğinin de \% 12 - 20 arasında değiştiği bildirilmiştir (Fox, 2010). Dolayısıyla bu sonuçlar, arpa tanelerlinin yem değerinde ve buna bağlı olarak hayvan performansinda farklılıklara yol açabilecektir. Bazı araştırmacılar (Grimson ve ark., 1987; Mathison ve ark., 1991) hacım ağırlığının zayıf bir kalite gösterge olduğunu bildirmelerine rağmen, geleneksel olarak arpa da dahil birçok tahılın kalite ölçüsü olarak bin dane ağırlığı kullanılmaktadır (Hinman ve ark., 1995). Bununla birlikte, arpa çeşitlerinin yem değeri ve dolayısıyla hayvan performansında oluşturduğu farklılıklar, bin dane ağırlığından ziyade kimyasal kompozisyon ile ilişkilidir (Grimson ve ark.,, 1987).

Arpanın enerji değeri, nişasta içeriğinin düşük ve selüloz, lignin ve nişasta olmayan polisakkaritler, glukan ve arabinoksilan (hemiselüloz) gibi sindirilemez lif bileșenlerinin yüksekliğinden dolayı mısır ve buğdaya göre daha düşüktür (Nikkhah, 2012). Arpa geviş getiren hayvalar, domuzlar ve kümes hayvanları için enerji kaynağı olmanın yanı sıra aynı zamanda bir protein kaynăğıdır. Yüzde 9.6-14.1 arasında HP ve yaklaşık \%2 ham yağ (HY) içeren arpa lizin ve treonin amino asitlerince fakir, triptofan amino asiti bakımından zengin bir enerji kaynağıdır (Biel ve Jayncno, 2013).

Arpa ruminantlar için lezzetli bir yem olup hem süt hem de özellikle besi sığırları için hazırlanan karmaların büyük bir bölümünü oluşturmaktadır. Bu nedenle, bu hayvanlar için dengeli bir karma hazırlanabilmesi ve başarılı bir beslenme programının uygulanabilmesi, yöresel olarak üretilen arpa varyetelerinin yem değerinin bilinmesi bağlıdır. Nitekim, dünyanın farklı ülkelerinde olduğu gibi (Micek ve ark., 2005; Kowieska ve ark., 2011; Biel ve Jayncno, 2013; Sterna ve ark., 2015; Alijosius ve ark., 2016; Lee ve ark., 2016) Türkiye'de üretimi yapılan birçok arpa çeşidinin (İnal ve ark., 2000; Abaş ve ark., 2005; Alkan ve Kandemir, 2015; Oral ve ark., 2017; Sevim ve ark., 2017; Güney 2019; Kızılgeçi ve ark., 2019) yem değerinin belirlenmesi ile ligi yoğun araştırmalar yapılmıştır. Yine
Türkiye'de üretimi yapılan Karatay-94, Beyşehir, Ayrancı, Kral-97 ve Larende gibi arpa çeşitlerinin dane verimi ve protein oranı gibi çeşitli özellikleri ile ilgili değişik ekolojik şartlarda çok sayıda araştırma yürütülmüştür (Aydoğan ve ark., 2011; Çöken ve Akman, 2016). Dolayısıyla bu çalışma, Türkiye'de yetiştirilen ve piyasada yer alan farklı arpa çeşidinin kimyasal bileşiminin yanı sıra in vitro gaz üretimi (GÜ), organik madde sindirilebilirliği (OMS), metabolize edilebilir enerji (ME) ve net enerji laktasyon $\left(\mathrm{NE}_{\mathrm{L}}\right)$ içeriklerinin saptanması ve yem değerlerinin karşılaştırılması amacıyla yapılmıştır.

\section{Materyal ve Yöntem}

\subsection{Yem ve hayvan materyali}

Araştırmanın yem materyalini 2019 yllında Bahri Dağdaş Uluslararası Tarımsal Araştırma Enstitüsü'nden elde edilen beş farklı arpa çeşidi (Karatay-94, Beyşehir, Ayranc1, Kral-97 ve Larende) oluşturmuştur. Her bir çeşide ait ikişer kg'lık 3 örnek alınmış ve ağızı kilitli plastik torbalara konularak etiketlenmiş ve analizlerin yapılacağı laboratuvara (Ondokuz Mayıs Üniversitesi Veteriner Fakültesi Hayvan Besleme ve Beslenme Hastalıkları Anabilim Dalı) getirilmiştir. In vitro gaz üretiminin belirlenebilmesi için mısır silajı ve kg kuru maddede (KM) $190 \mathrm{~g}$ HP ve $2850 \mathrm{kcal}$ ME içeren bir kesif yem karması (50/50 oranında) ile beslenen 3 baş Simmental ırkı ineğin rumen sıvısı kullanılmıştır. Florya Entegre Et Sanayi, Samsun mezbahanesinden kesimi yapılan hayvanların rumen içerikleri, $39{ }^{\circ} \mathrm{C}$ 'de ve $\mathrm{CO}_{2}$ ilave edilen termos içerisine alınmıştır.

\subsection{Kimyasal analizler}

Beş farklı arpa çeşidine ait numunelerinin besin madde analizleri 3 paralel olarak yapılmıştır. Analiz öncesi her bir çeşide ait örnekler $1 \mathrm{~mm}$ elek çapına sahip değirmende ögütülmüştür. Arpa örneklerinin KM, HP, HY, kül analizleri AOAC (2006) tarafindan onaylanmış protokollere göre yapılmıştır. Örneklerin hücre duvarı bileşenleri NDF, ADF ve asit deterjan lignin (ADL) içerikleri Van Soest ve ark. (1991) tarafından açılandığ 1 şekilde ANKOM 200 Fiber Analyzer (ANKOM Technology, 2008) ile analiz edilmiştir. Her bir arpa varyetesine ait örneklerin nişasta içeriği aşağıdaki formül kullanılarak belirlenmiştir (Fant ve ark., 2020).

$$
\% \text { nişasta }=\mathrm{OM}(\%)-\mathrm{HY}(\%) \mathrm{NDF}(\%)-\text { şeker }(\%)
$$

Burada, OM: organik maddedir. Tüm arpa çeşitleri için şeker konsantrasyonu $28 \mathrm{~g} \mathrm{~kg}^{-1} \mathrm{KM}$ olarak alınmıştır (Feedipedia, 2020.) 


\subsection{In vitro gaz üretimi}

Arpa çeşitlerinin in vitro sindirilebilirlikleri ANKOM GÜ sistemi kullanılarak Menke ve Steingass (1987) tarafından açıklandığı gibi belirlenmiştir. Bu amaçla 3, 6, 12, 24, 48, 72 ve 96 saat inkübasyon sonrasında tüpler içerisinde üretilen gaz miktarları kümülatif basınç (mL) esas alınarak ölçülmüştür. Arpa örneklerinin $\mathrm{ME}$, net enerji laktasyon $\left(\mathrm{NE}_{\mathrm{L}}\right)$ ve $\mathrm{OMS}$ (\%) değerleri, aşağıdaki formüller kullanılarak hesaplanmıştır (Menke ve Steingass, 1987).

$$
\begin{aligned}
\mathrm{ME}\left(\mathrm{MJ} \mathrm{kg}^{-1} \mathrm{KM}\right)= & 0.157 \mathrm{GÜ}+0.0084 \mathrm{HP}+0.022 \mathrm{HY} \\
& -0.0081 \mathrm{HK}+1.06 \\
& \left(\mathrm{n}=200 / \mathrm{r}^{2}=0.94\right)
\end{aligned}
$$

$$
\begin{aligned}
\mathrm{NE}_{\mathrm{L}}\left(\mathrm{MJ} \mathrm{kg}^{-1} \mathrm{KM}\right)= & 0.115 \mathrm{GÜ}+0.0054 \mathrm{HP}+0.014 \mathrm{HY}- \\
& 0.0054 \mathrm{HK}-0.36 \\
& \left(\mathrm{n}=200 / \mathrm{r}^{2}=0.93\right)
\end{aligned}
$$

$$
\begin{aligned}
\text { OMS }(\% \mathrm{KM})= & 0.9991 \mathrm{GÜ}+0.0595 \mathrm{HP}+0.0181 \mathrm{HK} \\
& +9.00 \\
& \left(\mathrm{n}=200 / \mathrm{r}^{2}=0.92\right)
\end{aligned}
$$

GÜ: 24 saatlik fermantasyon sonucu açığa çıkan gaz miktarı (mL); HP: ham protein ( $\left.\mathrm{g} \mathrm{kg}^{-1} \mathrm{KM}\right)$; HY: ham yağ ( $\left.\mathrm{g} \mathrm{kg}^{-1} \mathrm{KM}\right)$; HK: ham kül $\left(\mathrm{g} \mathrm{kg}^{-1} \mathrm{KM}\right)$

\subsection{Istatistiksel analizler}

Tüm veriler SPSS istatistik (SPSS, 2013; version 21.0) paket programinın Compare Means procedure temelinde tek yönlü varyans analizine tabii tutulmuştur. Ortalamalar arasındaki farklılıkları tanımlamak için Tukey Çoklu Karşılaştırma Testi kullanılmıştır. Ortalama farklılıklar $\mathrm{P}<0.05$ 'te anlamlı kabul edilmiştir.

\section{Bulgular ve Tartışma}

\subsection{Besin maddeleri içeriğ $i$}

Arpa varyetelerinin HP içerikleri \%9.72 (Ayranc1) ve 11.91 (Karatay-94) arasında değişmiştir $(\mathrm{P}<0.05$, Çizelge 1). Karatay-94, Larende, Beyşehir ve Kral-97 çeşitleri arasında HP içeriği bakımından fark bulunmamıştır $(\mathrm{P}>0.05)$. Arpa çeşitlerinin HP içeriği ilgili sonuçlar, Bile ve Jayncno (2013)'nın farklı arpa varyeteleri arasında HP içeriği bakımından farklılık bulunmadığı sonucunu kısmen desteklemiştir. Mevcut çalışmadaki HP içeriklerinin sonuçlar bazı arpa varyetelerinin HP düzeylerinden daha düşük (İnal ve ark., 2000; Abaş ve ark., 2005; Lee ve ark., 2016; Güney 2019; Kızılgeçi ve ark., 2019), bazı arpa varyeteleri ile benzer olması (Micek ve ark., 2005; Biel ve Jayncno, 2013; Alijosius ve ark., 2016). Bu durum, varyete, iklim ve çevre gibi faktörlere bağlı olarak topraktaki alınabilir azotun oranının tanedeki protein miktarını etkilenmesi ile ilgilidir (Elgün ve ark., 2001).

Çalışmamızda arpa çeşitlerinin HY içerikleri (\%1.36-1.88) arasında farklılık saptanmamıştır $(\mathrm{P}>0.05$, Çizelge 1). Alijosius ve ark. (2016), bazı yazlık ve kışlık 12 arpa çeşidinin ortalama HY içeriğinin \%1.581.71 arasında değiştiğini bildirmiştir. Mevcut ve Alijosius ve ark. (2016)'nın çalışma sonuçlarının aksine arpa çeşitlerinin HY içeriğinin \%2.0-2.3 arasında değiştiği bildiren çalışmalar da vardır (Sterna ve ark., 2015).

Arpa çeşitlerinin kül düzeyleri (\%1.59-2.06) arasında da istatistiksel olarak fark bulunmamıştır (Çizelge 1). Bazı araştırmacılar (Aldemir ve Karslı, 2012; Alkan ve Kandemir, 2015; Güney, 2019) arpanın HK içeriğinin \%1.63-2.79 arasında değiştiğin saptamışlardır. Kül içeriği bakımından çeşitler arasındaki bu varyasyon, arpa danelerin arasina toprak karışması ile ilgili olabilir

Arpa varyeteleri arasinda NDF (\%19.86-23.37 arasinda), ADF (\%5.38-8.52 arasinda) ve ADL (\%1.232.95) içerikleri bakımından farklılıklar önemli bulunmuştur ( $\mathrm{P}<0.001$, Çizelge 1). En yüksek ADF, NDF ve ADL içeriği sırasıyla Kral-97 çeşidinde, en düşük ise Larende çeşidinde belirlenmiştir $(\mathrm{P}<0.05)$. Yazlık ve kışlık arpa çeşitlerinin ADF, NDF ve ADL içeriklerinin Polonya'da (Kowieska ve ark., 2011) sirasiyla \%10.4-10.7, 25.3-26.9 ve 1.59-2.49 arasinda Litvanya'da (Alijosius ve ark.,2016) ise \%6.31-6.86, $\% 18.76-20.87$ ve \%1.33-1.37 arasında olduğu bildirilmiştir. Aldemir ve Karslı (2012) arpanın ADF ve NDF değerini sırasıyla \%6.73 ve 35.87 olarak tespit etmişlerdir. Alkan ve Kandemir (2015) ve Güney (2019) farklı arpa çeşitlerinde ADF içeriğinin sırasıyla \%3.656.49 ve \%6.53-9.07; NDF içeriğinin ise \%23.4-42.41 ve \%19.77-26.61 arasında olduğunu saptamışlardır. Mevcut ve daha önceki çalışma ADF ve NDF ile ilgili sonuçları arasında görülen farklılıkların en önemli nedeninin çeşitlerinin kavuz miktarı ile ilgili olduğu düşünülmektedir. Çalışmamızda incelenen arpa çeşitlerinin kavuz oranları belirlenmemiş olmasına rağmen, arpada toplam kavuz oranının tane ağırlığının \%15-25 arasında değiştiği (Rode ve Beauchemin, 1995) ve kavuzun NDF oranının > \%70 (Zhao ve ark., 2015) olduğu bildirilmiştir. Başka bir çalışmada (Hoije ve ark.,, 2005) ise kavuzun kimyasal kompozisyonun $\% 23.0$ selüloz, \%32.7 hemiselüloz, \%21.4 lignin, \%1.6 asetil gruplar ve $\% 21.3 \%$ diğer bileşenlerden oluştuğu ifade edilmiştir. İncelenen arpa çeşitlerinin besin maddeleri içerikleri ile ilgili sonuçlar, varyete, çevre ve toprak gibi faktörlerin tahılların besin maddeleri içeriğini etkilediği fikrini doğrulamaktadır (Elgün ve ark., 2001).

Endosperm, tahıl tanelerindeki nişastanın çoğu için bir saklama bölmesi görevi görür ve endosperm oranındaki fark, nişastanın konsantrasyonuna yansıtmaktadır (Evers ve Millar, 2002). Bu çalışmada, nişasta konsantrasyonundaki gözlemlenen en büyük 
fark, Larende ve Kral-97 çeşitleri arasında (\%2.8) saptanmıştır (Çizelge 1). Bu çalışmada, nişasta konsantrasyonunu kimyasal analizle saptanmamış olmasina rağmen, hesap ile belirlenen değerler Holtekjolen ve ark. (2006) tarafindan belirlenen değer (\%51-64) arasında bulunmuştur. Micek ve ark. (2005), nişasta içeriğini yazlık arpa çeşitlerinde \%62.3-67.7 arasında, kışlık arpa çeşitlerinde ise \%55.4-67.2 arasında olduğunu belirlemiştir. Oral ve ark. (2017), bazı yerli arpa varyetelerinin nişasta düzeyinin \%68.470.5; Kızılgeçi ve ark. (2019) \%59.7-62.2; Güney (2019) ise \%40.92-47.26 arasında değiştiğini bildirmişlerdir.

Yem maddelerindeki fermente olabilen maddelerin kısa zincirli yağ asitlerine fermantasyonu sonucu üretilen GÜ miktarı (Mauricio ve ark., 2001) bakımından incelenen arpa çeşitleri arasında farklılık bulunmamıştır (Çizelge 2). Bu çalışmada kullanılan arpa çeşitlerinin GÜ miktarlarının literatürde bildirilen değerlerden daha düşük olduğu belirlenmiştir. Örneğin, Abaş ve ark. (2005) ve Sevim ve ark. (2017) arpanın GÜ değerlerinin sirasiyla $47.1-61.6$ ve $64.0-72.5 \mathrm{~mL}$ $200 \mathrm{mg}^{-1} \mathrm{KM}$ arasında değiştiğini saptanmışlardır. Çalışmalar arasındaki bu farklılıklar arpa tanelerindeki fermente olabilen maddelerin oranı ve yıkılım hızındaki farklılıklardan kaynaklanmış olabilir (Micek ve ark., 2005).

Çizelge 1. İncelenen arpa çeşitlerinin besin maddeleri içeriği, \% KM

Table 1. Nutrient matter composition of barley varieties, \% DM

\begin{tabular}{lcccccccc}
\hline Çeşitler & OM & HP & HY & HK & ADF & NDF & ADL & Nişasta \\
\hline Larende & 89.55 & $11.83^{\mathrm{a}}$ & 1.88 & 1.59 & $5.38^{\mathrm{c}}$ & $19.86^{\mathrm{c}}$ & $1.23^{\mathrm{c}}$ & 53.17 \\
Beyşehir & 89.24 & $11.08^{\mathrm{a}}$ & 1.47 & 1.81 & $6.41^{\mathrm{b}}$ & $21.30^{\mathrm{b}}$ & $2.01^{\mathrm{b}}$ & 52.57 \\
Karatay-94 & 88.23 & $11.91^{\mathrm{a}}$ & 1.42 & 2.06 & $6.20^{\mathrm{b}}$ & $21.28^{\mathrm{b}}$ & $2.20^{\mathrm{b}}$ & 50.81 \\
Ayranc1 & 88.26 & $9.72^{\mathrm{b}}$ & 1.52 & 1.63 & $5.97^{\mathrm{b}}$ & $21.38^{\mathrm{b}}$ & $1.43^{\mathrm{c}}$ & 52.83 \\
Kral-97 & 88.62 & $10.71^{\mathrm{ab}}$ & 1.36 & 1.84 & $8.52^{\mathrm{a}}$ & $23.37^{\mathrm{a}}$ & $2.95^{\mathrm{a}}$ & 50.37 \\
OSH & 0.223 & 0.240 & 0.060 & 0.065 & 0.290 & 0.321 & 0.169 & 0.431 \\
$P$-değeri & 0.23 & $0.03^{*}$ & 0.09 & 0.13 & $<0.001^{* * *}$ & $<0.001^{* * *}$ & $<0.001^{* * *}$ & 0.114 \\
\hline KM: Kr & & & & & & & & \\
\hline
\end{tabular}

KM: Kuru madde, OM: Organik madde, HP: Ham protein, HY: Ham yăg, HK: Ham kül, ADF: Asit çözücüde çözünmeyen lif, NDF: Nötr çözücüde çözünmeyen lif, ADL: Asit çözücüde çözünmeyen lignin, OSH: Ortalamanın standart hatası,

a, b, c: Aynı sütunda farklı harflerle gösterilen ortalamalar arasındaki farklılık istatistiki olarak önemlidir

Araştırmada kullanılan arpa çeşitlerinin in vitro OMS'leri \%51.79 (Kral-97) ile 56.14 (Larende) arasında saptanmıș ve çeșitler arasındaki farklılıklar istatistiksel olarak önemli bulunmuştur $(\mathrm{P}<0.05$, Çizelge 2). Mevcut çalışmadaki OMS bulguları ile önceki araştırma bulguları tutarsız ve elde edilen değerler literatürde bildirilen sinırların altında olduğu saptanmıştır. Nitekim, Abaş ve ark. (2005), farklı arpa çeşitlerinin in vitro OMS değerlerinin \%61.10-89.82 arasında değiştiğini bildirirken, İnal ve ark. (2000) ortalama OMS değerini \%85 olarak saptanmıştır. Aynı değer başka bir in vitro çalışmada (Micek ve ark., 2005) yazlık ve kışlık arpa çeşitlerinde sırasıyla \%78.8 ve 83.3 bildirilmiştir. Arpanın OMS sindirilebilir ile ilgili mevcut ve literatür bildirişleri arasındaki varyasyon, arpanın çeşidi, kavuz oranı, yapısal karbonhidrat içeriği, amiloz/amilopektin oranı, nişasta-lipid ve nişastaprotein kompleksinden kaynaklanmış olabilir (Grove ve ark., 2003; Gomez ve ark., 2016). Gerçekten de Grove ve ark. (2003) arpa kavuzunun, arpa samanından daha düşük ruminal yıkımlanabilirliğe sahip olduğunu ve bu durumun OMS sindiriminde farklılıklara yol açtığı belirtilmiştir.

Bir yem maddesinin enerji $\left(\mathrm{ME}, \mathrm{NE}_{\mathrm{L}}\right)$ içeriği, o yem maddesinin GÜ değeri ve besin maddelerinin belli katsayılarla çarpımından elde edildiğinden, yem maddesinin enerji değeri ile bu parametreler arasında pozitif bir ilişkiden söz edilebilir. Nitekim Çizelge 1'de HP ve HY, Çizelge 2'deki GÜ değerleri incelendiğinde en düşük ve en yüksek $\mathrm{NE}_{\mathrm{L}}$ ve $\mathrm{ME}$ değerler sırasıyla 4.76 ve 7.74 ve $\mathrm{MJ} \mathrm{kg}^{-1} \mathrm{KM}$ (Kral-97) ile 5.06 ve 8.44 MJ $\mathrm{kg}^{-1} \mathrm{KM}$ (Larende) olarak saptanmıştır $(\mathrm{P}<0.05$, Çizelge 2). Fakat, mevcut çalışmada elde edilen arpa çeşitlerinin enerji içeriklerinin literatürdeki diğer çalışmalardan elde edilen enerji değerlerine göre daha düşük bulunmuştur. Örneğin Denek ve Deniz (2004), arpanın ME içeriklerini $12.511 \mathrm{MJ} \mathrm{kg}^{-1} \mathrm{KM} ; \mathrm{NE}_{\mathrm{L}}$ değerini de $8.111 \mathrm{MJ} \mathrm{kg}^{-1} \mathrm{KM}$ olarak tespit ederken; Sevim ve ark. (2017), üç arpa çeşidinde sırasıyla bu değerleri 12.44-12.86 ve 7.16-7.98 $1 \mathrm{MJ} \mathrm{kg}^{-1} \mathrm{KM}$ olarak 
Çizelge 2. İ́ncelenen arpa çeşitlerinin in vitro gaz üretimi (GÜ, 24 saat in vitro inkübasyonda), metabolize edilebilir enerji (ME), net enerji laktasyon $\left(\mathrm{NE}_{\mathrm{L}}\right)$ ve organik madde sindirilebilirlik (OMS) düzeyleri

Table 2. In vitro gas production (24 h in vitro incubation), organic matter digestibility metabolizable energy and net energy lactation contents of the some barley varieties

\begin{tabular}{lcccc}
\hline Çeşitler & $\begin{array}{c}\mathrm{GÜ}, \\
\left(\mathrm{mL} 200 \mathrm{mg}^{-1} \mathrm{KM}\right)\end{array}$ & $\begin{array}{c}\text { OMS } \\
(\%)\end{array}$ & $\begin{array}{c}\mathrm{ME} \\
\left(\mathrm{MJ} \mathrm{kg}^{-1} \mathrm{KM}\right)\end{array}$ & $\begin{array}{c}\mathrm{NE}_{\mathrm{L}} \\
\left(\mathrm{MJ} \mathrm{kg}^{-1} \mathrm{KM}\right)\end{array}$ \\
\hline Larende & 46.51 & $56.14^{\mathrm{a}}$ & $8.44^{\mathrm{a}}$ & 5.06 \\
Beyşehir & 44.31 & $53.89^{\mathrm{ab}}$ & $8.07^{\mathrm{ab}}$ & 4.80 \\
Karatay-94 & 44.18 & $53.81^{\mathrm{ab}}$ & $8.05^{\mathrm{ab}}$ & 4.79 \\
Ayranc1 & 43.44 & $52.95^{\mathrm{ab}}$ & $7.94^{\mathrm{ab}}$ & 4.69 \\
Kral-97 & 42.23 & $51.79^{\mathrm{b}}$ & $7.74^{\mathrm{b}}$ & 4.56 \\
OSH & 0.50 & 0.52 & 0.09 & 0.06 \\
P-değeri & 0.06 & $0.05^{*}$ & $0.05^{*}$ & 0.06 \\
\hline
\end{tabular}

SHO: Ortalamanın standart hatası

a, b: Aynı sütunda farklı harflerle gösterilen ortalamalar arasındaki farklılık istatistiki olarak önemlidir

bulmuşlardır. Benzer şsekilde Güney (2019), ME değerini 10.04-10.83 MJ kg-1 KM ve İnal ve ark. bildirmişlerdir. $\mathrm{Bu}$ durumun, mevcut çalışmada incelenen arpa çeşitlerinin fermente olan organik madde mitarının düşük oluşu (Sanford ve ark., 2003) bir neden olarak gösterilebilir. Nitekim ME ve NEL değerinin hesaplanmasında GÜ miktarı daha yüksek bir katsayı (sırasıyla 0.1570 ve 0.115 ) ile çarpılmaktadır.

\section{Sonuç}

Araştırma sonuçlerı, Larende, Beyşehir, Karatay-97 ve Ayrancı çeşidinin HP hariç ADF, NDF ve ADL içeriği bakımından Kral-97 çeşidinden daha düşük, nişasta, GP ve NEL bakımından incelenen arpa çeşitlerinin benzer olduğu göstermiştir. Buna ilaveten Larende çeşidinin OMS ve ME içeriğinin Kral-97 çeşidinden istatistiksel olarak daha yüksek tespit edilmiştir. Bu sonuçlar, geviş getiren hayvanların beslenmesinde açısından incelenen çeşitler hakkında temel bilgilerin sağlanması yanında, bu çeşitlerinin geviş getiren hayvanların beslenmesinde başarılı bir şekilde kullanılabileceğini de göstermiştir.

\section{Kaynaklar}

Abaş, İ., Özpınar, H., Kutay, H.C., Kahraman, R., 2005. Determination of the metabolizable energy (ME) and net energy lactation (NEL) contents of some feeds in the Marmara Region by in vitro gas technique. Turkish Journal of Veterinary and Animal Sciences, 29: 751-757.

Aldemir, R., Karslı, M.A., 2012. Yaş şeker pancarı posası silajının arpa yerine kullanımının koyunlarda duodenuma geçen toplam protein üzerine etkisi: 1.Besin madde sindirimi ve mikrobiyal protein sentezi. Yüzüncü Y1l Ünivetsitesi Veteriner Fakültesi Dergisi, 23 (2): 89-98.
Alijosius, S., Svirmickas, G.J., Kliseviciute, V., Gruzauskas, R., Sasyee, V., Raceviciute-Stupeliene, A., Dauksiene, A., Dailidaviviene, J., 2016. The chemical composition of different barley varieties grown in Lithuania. Veterınarıja Ir Zootechnıka, 73 (95): 9-13.

Alkan, R.A., Kandemir, N., 2015. Tokat yerel arpa çeşidi içinden seçilen saf hatların bazı gıda, yem ve tarımsal özellikler bakımından varyasyonları. Tarla Bitkileri Merkez Araştırma Enstitüsü Dergisi, 24 (2):124-139

AOAC. 2006. Official methods of analysis. 18th Ed. Association of Official Analytical Chemists, Washington, DC, USA.

Aydoğan, S., Şahin, M., Göçmen, A.A., Ayranc1, R., 2011. Konya koşullarına uygun yüksek verimli ve kaliteli arpa genotiplerinin belirlenmesi. Selçuk Tarım ve Gida Bilimleri Dergisi, 25(1): 10-16.

Biel, W., Jacyno, E., 2013. Chemical composition and nutritive value of spring hulled barley varieties. Bulgarian Journal of Agricultural Science, 19 (4): 721-727.

Çöken, İ., Akman, Z. Isparta ekolojikkoşullarında bazı arpa (Hordeum vulgare L.) çeşitlerinin verim ve kalite özelliklerinin belirlenmesi. Süleyman Demirel Üniversitesi Fen Bilimleri Enstitüsü Dergisi, 20(1): 91-97.

Denek, N., Deniz, S., 2004. Ruminant beslemede kullanılan bazı dane yemlerin enerji düzeylerinin in vivo ve in vitro metotlarla belirlenmesi. Turkish Journal of Veterinary and Animal Science, 28: 185193.

Elgün, A., Türker, S., Bilgiçli, N., 2001. Tahıl ve ürünlerinde analitik kalite kontrolü. Selçuk Üniversitesi Ziraat Fakültesi Gıda Mühendisliği Bölümü, Yayın No: 2, Konya 
Evers, T., Millar, S., 2002. Cereal grain structure and development: Some implications for quality. Journal of Cereal Science, 36: 261-284. DOI: 1006/jcrs.2002.0435

Fant, P., Ramin, M., Jaakkola,, S., Grimberg A., Carlsson, A. S., Huhtane, P., 2020. Effects of different barley and oat varieties on methane production, digestibility, and fermentation pattern in vitro. Journal of Dairy Science, 103(2): 1404-1415. DOI: 10.3168/jds.2019-16995

Feedipedia, 2020. Animal feed resources information system. Tables of chemical composition and nutritional value. Available from URL: https://www.feedipedia.org/node/227 ( Erişim tarihi:. 01 Ocak 2020).

Fox, G.P., 2010. Chemical composition in barley grains and malt quality. In: Zhang, G., Li.C. (Eds). Genetics and Improvement of Barley Malt Quality. Springer, Berlin, Heidelberg. pp. 64-99.

Gomez, L.M., Posado, S.L., Olivera, M., 2016. Starch in ruminant diets: a review. Revista Colombiana de Ciencias Pecuarias, 29: 77-90. DOI: 10.17533/udea.rccp.v29n2a01.

Grimson, R. E., Weisenburger, R. D., Basarab, J. A., Stilborn, R. P., 1987. Effects of barley volumeweight and processing method on feedlot performance of finishing steers. Canadian. Journal of. Animal Science, 67(1): 43-53. DOI: 10.4141/cjas87-006

Grove, A.V., Hepton, J., Pas, H.C.W., 2003. Composition and ruminal fermentability of barley grain, hulls, and straw as affected by irrigation level, planting date, and variety. The Professionaol Animal Scientist, 19(4); 273-280. DOI: 10.15232/S10807446(15)31422-4

Güney, M., 2019. Effect of grain processing at different barley varieties on nutrient composition, starch contents and in vitro digestion parameters. Progree in Nutrition, 21(3): 715-721. DOI: 10.23751/pn.v21i3.8571

Hinman, D.D., Sorensen, S.J., Momont, P.A., 1995. Influence of barley bulk density and blended barley on the performance of beef cattle and diet digestibility. Proceedings, Western Section, American Society of Animal Science, 46: 443.

Hoije, A., Grondahl, M., Tommeraas, K., Gatenholm, P., 2005. Isolation and characterization of physicochemical and material properties of arabinoxylans from barley husks. Carbohydrate Polymers, 61: 266-275. DOI: 10.1016/j.carbpol.2005.02.009

Holtekjolen, A.K., Uhlen, A.K., Brathen E., Sahlstrom, S., Knutsen S.H., 2006. Contents of starch and nonstarch polysaccharides in barley varieties of different origin. Food Chemistry, 94: 348-358. DOI: 10.1016/j.foodchem.2004.11.022

İnal, F., Coşkun, B., Balevi, T., Umucalılar, H.D., Gülşen, N., Özkara, R., 2000. The determination of viscosity in barley and using possibilities of barleys, having different viscosity, supplemented with enzyme in layer diets. Indian Journal of Animal Science, 70: 1250-1254.

Kızılgeçi, F., Yıldırım, M., Akıncı, C., Albayrak, Ö., 2019. Arpada tane verimi ve kalite özellikleri üzerine genotip ve çevrenin etkileşimi. Kahraman Maraş Sütçü İmam Üniversitesi Tarım ve Doğa Dergisi, 22(3): 346-353. DOI: 10.18016/ksutarimdoga.vi.499013

Kowieska, A., Lubowicki, R., Jaskowska, I., 2011. Chemical composition and nutritional characteristics of several cereal grain. Acta Scientiarum Polonorum Zootechnica, 10 (2): 37-50.

Lee, j., Nam, D.S., Kong, C., 2016. Variability in nutrient composition of cereal grains from different origins. Springer Plus, 419: 2-6. DOI: 10.1186/s40064-016-2046-3

Mathison, G.W., Hironaka, R., Kerrigan, B.K., Vlach, I., Milligan, L.P., Weisenburger, D., 1991. Rate of starch degradation, apparent digestibility and rate and efficiency of steer gain as influenced by barley grain volume-weight and processing method. Canadian Journal of Animal Science, 71: 867. DOI: 10.4141/cjas91-102

Mauricio, R., Owen, E., Mould, F.L., Givens, I., Teodorou, M.K., France, J., Davies, D.R., Dhanoa, M.S., 2001. Comparison of bovine rumen liquor and bovine faeces as inoculum for an in vitro gas production technique for evaluating forages. Animal Feed Science and Technology, 89: 33-48. DOI: 10.1016/S0377-8401(00)00234-0

Menke, K.H., Steingass, H., 1987. Schätzung des energetischen Futterwerts aus der in vitro mit Pansensaft bestimmten Gasbildung und der chemischen Analyse. II. Regressionsgleichungen. Übersich Tierernäh. 15: 59-94.

Micek, P., Kowalski, Z.M., Borowiec, F., 2005. Effect of barley cultivar on the chemical composition and rumen degradability of dry matter, protein and starch. Journal of Animal and Feed Sciences, 14(1): 279-282. DOI: $10.22358 / \mathrm{jafs} / 70538 / 2005$

Nikkhah, A., 2012. Barley grain for ruminants: A global treasure or tragedy. Journal of Animal Science and Biotechnology, 3(22): 1-9.

Oral, E., Kendal, E., Doğan, Y., 2017. Bazı yazlık arpa (Hordeum vulgare L.) genotiplerinin verim ve kalite yönünden değerlendirilmesi. Iğdır Üniversitesi Fen Bilimleri Enstitüsü Dergisi, 7(1): 31-38.

Reynolds, W.K., Hunt, C.W.J., Eckert, W., Hall, M.H., 1992. Evaluation of the feeding value of barley as affected by variety and location using near infrared reflectance spectroscopy. Proceedings, Western Section, American Society of Animal Science, 43: 498. DOI: 10.1016/j.livsci.2007.01.144

Rode, L.M., Beauchemin, K.A., 1995. Utilization of barley based diets for feedlot cattle. Proceedings, 
Western Section, American Society of Animal Science , 46:606-607. DOI: 10.4141/A04-060

Sanford, B. J., Grove, A.V., Hunt, C.W., 2003. Evaluation of barley characteristics that are associated with digestible energy for beef cattle. The Professional Animal Scientist, 19: 281-285. DOI: 10.15232/S1080-7446(15)31423-6

Sevim, B., Ayaşan, T., Ülger, İ., Ergul, Ş., Aykanat, S., Coşkun, A.M., 2016. Farklı maltlık arpa çeşitlerinin besin değerlerinin in vitro gaz üretim tekniği kullanılarak tespiti. Türk Tarım - Gıda Bilim ve Teknoloji Dergisi, 5(10): 1216-1220. DOI: 10.24925/turjaf.v5i10.1216-1220.1386

Sterna, V., Zute, S., Jakobsone, I., 2015. Grain composition and functional ingredients of barley varieties created in Latvia. Proceedings of the Latvian Academy of Sciences, 69: 158-162. DOI: 10.1515/prolas-2015-0023

TÜIK, 2018. Türkiye İstatistik Kurumu. Bitkisel üretim istatistikleri. Available from URL: http://www.tuik.gov.tr (Erşim tarihi: 31 Aralık 2019).

Van, Soest P.J., Robertson, J.D., Lewis, B.A., 1991. Methods for dietary fibre, neutral detergent fibre and non-starch polysaccharides in relation to animal nutrition. Journal of Dairy Science, 74: 3583-3597. DOI: 10.3168/jds.S0022-0302(91)78551-2

Zhao, Y.L., Yan, S.M., He, Z., Anele U.C, Swift M.L., A Mcallister, T., Yang, W., 2015. Effects of volume weight, processing method and processing index of barley grain on in situ digestibility of dry matter and starch in beef heifers. Animal Feed Science and Technology, 199: 93-103. DOI: 10.1016/j.anifeedsci.2014.11.005 